\title{
PRELIMINARY EVALUATION OF THE ANTIMICROBIAL ACTIVITY OF SOME SPICES USED AS ADDITIVES IN TOMATO SAUCE PRODUCTS
}

Irina Mladenoska*, Darko Dimitrovski

(ORIGINAL SCIENTIFIC PAPER)

Department of Food Technology and Biotechnology, Faculty of Technology and Metallurgy, University of Ss. "Cyril and Methodius", UDC 664.843.5:635.64:635.7:579

Skopje, Macedonia

The aim of this work was preliminary evaluation of the antimicrobial activity of several additives that can be used in tomato sauce products. For this purpose, several frequently used spices and the food supplement monolaurin were applied in the process of the tomato sauce production. The spices used were: garlic powder, basil leaves, cinnamon powder, milled chili peppers and table salt. Several different wild types of fungi were isolated from the rotten tomato and rotten apricot and the latter one was used as an infecting microorganism for tomato sauce products. The tests of the samples of the infected tomato sauces containing monolaurin, basil and cinnamon as additives had total cell counts of $3 \pm 1,8 \pm 1$ and $6 \pm 1 \mathrm{cfu} / \mathrm{mLx} 10^{6}$. Those results showed that the three selected additives are characterized with the highest potential to be used as antimicrobial additives in the tomato sauce production process.
Keywords: tomato sauce, monolaurin, basil, cinnamon, garlic, chilli peppers, antimicrobial activity

\section{Introduction}

The tomato plant (Solanum lycopersicum L.) is one of the most frequently produced agricultural species that is readily consumed worldwide as both fresh and processed food product. The ten largest producers of tomato products are: the USA, China, Italy, Turkey, Spain, Brazil, Portugal, Greece and Chile [1]. The calculation of its nutritional value, performed on the basis of the tomato sauce product, shows that the tomato contains a wide spectrum of nutritionally valuable compounds such as lycopene $(71.6 \%)$, vitamin C $(12 \%), \beta$-caroten $(17.2 \%)$ and vitamin $E(6 \%)$ [2]. It is also very rich in potassium (237 $\mathrm{mg} / 100 \mathrm{~g}$ tomato), while having a very low caloric value ( $3.89 \mathrm{~g}$ carbohydrates and $0.2 \mathrm{~g}$ fat/100 g tomato).

The common procedure for the industrial production of the tomato sauce assumes application of a vacuum evaporator. Both preservation and adjustment of a certain dry mass content might be achieved by using this technique. Besides common thermal procedures for the preservation of food products and conventionally used chemical preservation techniques, the unconventional techniques such as the addition of spices as natural preserving agents having antimicrobial activity are also widely investigated nowadays [3]. Natural antimicrobials such as essential oils of cinnamon [4-5], extracts of garlic [6-7], extracts of neem [8], basil $[9,10]$ and other spices, oleoresins, fatty acids and their esters are widely used in different food products in order to not only establish a safe food preservation process, but also give the product a new quality and the added value. Thus, monolaurin and other partial glycerides of fatty esters are well known for their pronounced antimicrobial activity, expressed both "in vitro" or as an additive incorporated in some kind of a food product [11-14]. While investigating the antimicrobial effect of monolaurin, Kabara and Marshal [15] found that this partial glyceride strengthens the immune system, and that its protective effect is evident during its consumption and sometime afterwards. The modern food technology should at the same time guarantee food safety and the preservation of nutritionally and biologically valuable compounds [3]. The last techniques are considered to be of a special interest today, when the struggle for the consumption of healthy food is especially expressed among the well informed consumers. Thus, the preservation of food products by using natural antimicrobials is a very important research area of the modern food technology.

Regarding the safety of tomato sauces, there are data that confirm that several moulds and bacterial species might be the cause of microbial spoilage of those food products [16].

In this work, several wild microbial strains were isolated from rotten fruits and vegetables. The isolated cultures were purified and morphologically analysed. The produced tomato sauces, all having different spices and monolaurin, were infected by the isolated wild microbial strain. A preliminary evaluation of the antimicrobial effect of the used spices and monolaurin was performed.

\section{Material and methods}

\section{Material}

Monolaurin which was used was in a form of capsules containing the powder with $99 \%$ of purity produced by „Ecological formulas", Concord, California, the USA.

The microbiological safety of tomato sauces was analysed by using Sabouraud agar medium. It was a product of Sigma-Aldrich, Buchs, Switzerland.

Two wild fungal strains were used as test microorganisms i.e. as infecting microorganisms of tomato products. The fungal strains (grey and green mould) were isolated from the

\footnotetext{
* Author address: Irina Mladenoska, Department of Food Technology and Biotechnology, Faculty of Technology and Metallurgy, University of Ss. "Cyril and Methodius“, Rudjer Bošković 16, Skopje, Macedonia

E-mail: irinaetf@t.mk

The manuscript received: February, 27, 2017.

Paper accepted: April, 03, 2017.
} 
rotten apricot and rotten tomato. The cultures were purified. Since the first one was more resistant to infections and had the more pronounced growth rate and concentration of cells $\left(1 \times 10^{9} / \mathrm{mL}\right)$, it was chosen for further experiments.

The spices: chilli peppers (Capsicum annuum), basil leaves (Ocimum basilicum), cinnamon (Cinnamomum cassia), garlic (Allium sativum) and the raw material for the food products, tomatoes, were all bought from the local food store.

\section{Methods}

Preparation of the tomato sauce

Tomatoes were first blanching for 8 minutes at the temperature of $88{ }^{\circ} \mathrm{C}$, milled, and then the water content was adjusted by a vacuum evaporation until the dry mass of $8.5 \%$ and a final volume of $340 \mathrm{~mL}$ were adjusted (Figure 1.1). Chilli peppers, basil leaves, cinnamon, garlic, salt and monolaurin were all used as additives in tomato sauce products. Monolaurin was added in the concentration of $0.2 \%(\mathrm{w} / \mathrm{v})$ and all other additives were added in the concentration of $0.5 \%(\mathrm{w} / \mathrm{v})$.

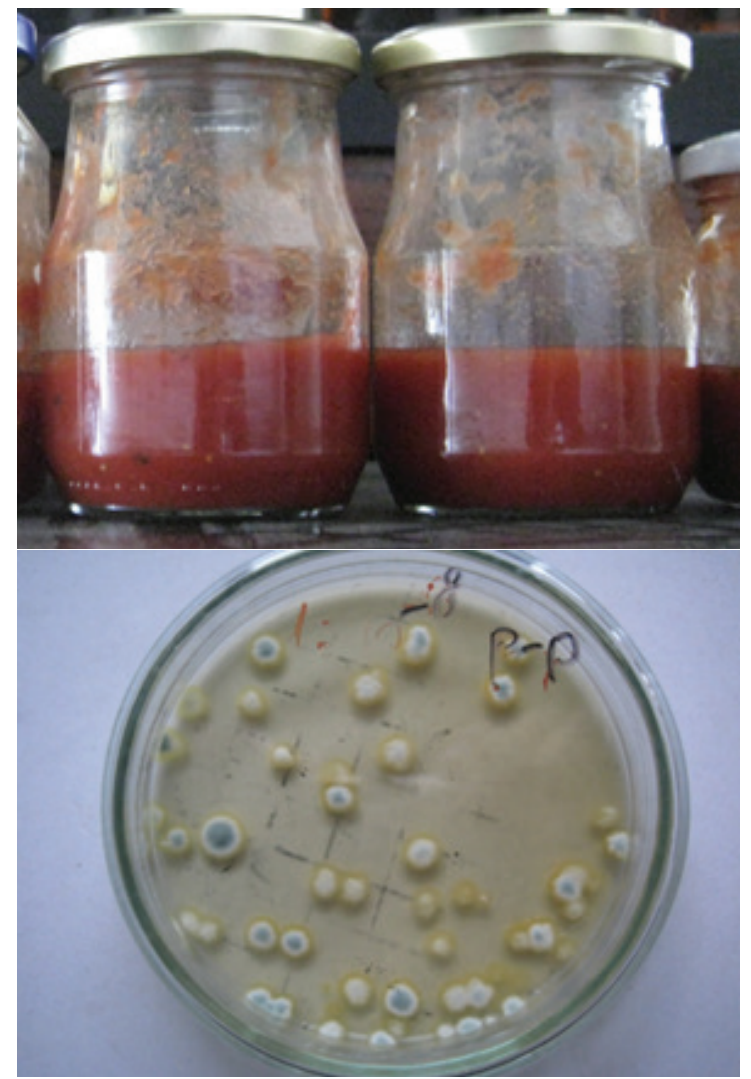

Figure 1. Tomato sauces produced in the Laboratory for Food Technology and Biotechnology, at the Faculty of Technology and Metallurgy, Skopje (1), and the counting of the colony forming units from the infected samples on a Petri Dish (2)

\section{Isolation of the microorganisms}

Several wild types of microorganisms were isolated from the rotten apricot and rotten tomato samples. The microorganisms were purified by a technique of repeated dilution and incubation, until a single cell colony was grown from each and every culture. The isolated strains were morphologically examined.
Infection of the tomato products

The tomato sauce was infected by $3 \mathrm{~mL}$ suspension containing $1 \times 10^{9}$ cells $/ \mathrm{mL}$. The infected tomato sauce was kept at $30^{\circ} \mathrm{C}$ for $72 \mathrm{~h}$.

\section{Preparation of the growth medium}

The Sabourand dextrose agar was prepared and autoclaved at $121^{\circ} \mathrm{C}$ for 35 minutes. After cooling, the medium was dosed aseptically in $12 \mathrm{~mL}$ quantities into Petri Dishes $(150 \times 25 \mathrm{~mm})$.

\section{Microbiological tests}

From all different tomato products, the $25 \mathrm{~mL}$ sample was taken and diluted with $225 \mathrm{~mL}$ sterile water. Then further dilutions of $10^{-5}, 10^{-6}$ and $10^{-7}$ were prepared. $1 \mathrm{~mL}$ of each dilution was taken and inoculated on a Petri Dish with $12 \mathrm{~mL}$ Sabourand agar. Thus inoculated Petri Dishes were incubated on $30^{\circ} \mathrm{C}$ for 4 days. Then, the number of the colonies grown from a single cell (colony forming unit) was counted (Figure 1.2).

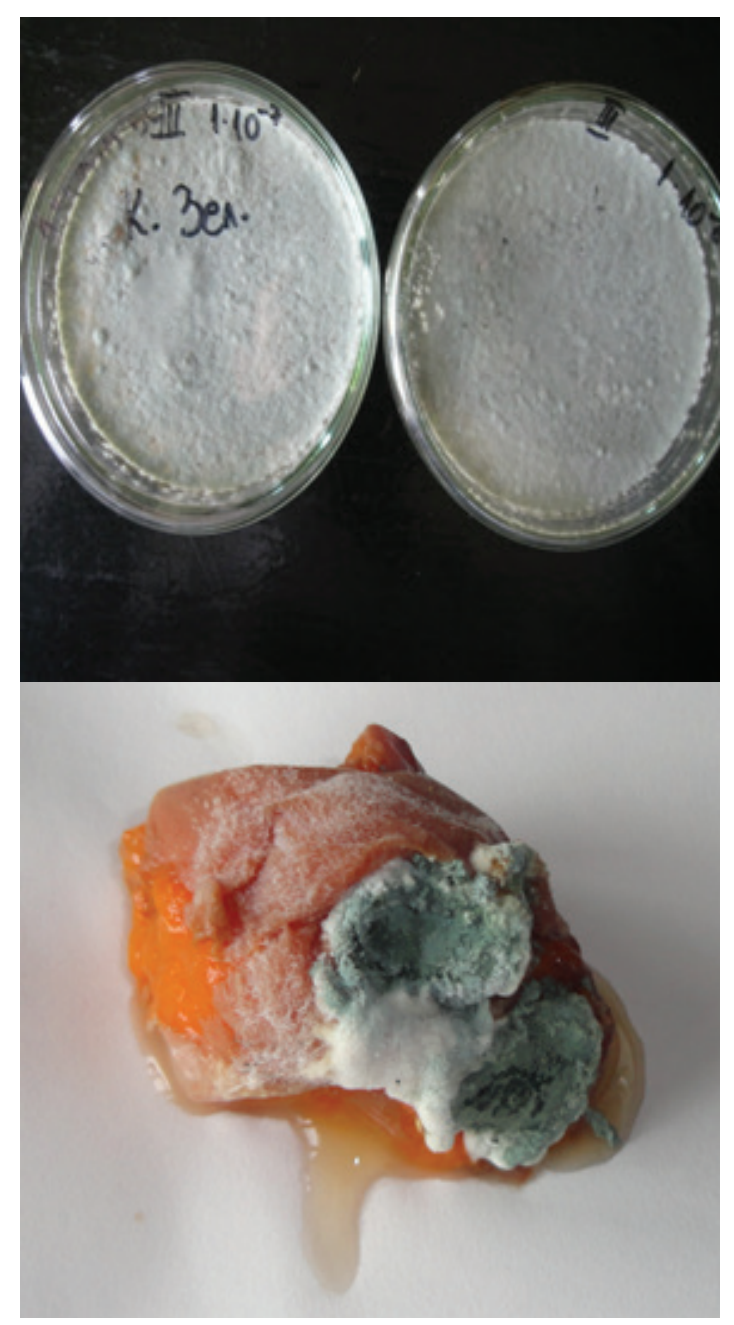

Figure 2. The wild green mold (1) isolated from the rotten apricot (2) in the Laboratory for Food Technology and Biotechnology, at the Faculty of Technology and Metallurgy, Skopje. 


\section{Results and discussion}

Isolation of wild type plant infecting microorganisms Several wild types of microbial strains were isolated from rotten tomatoes and rotten apricot. Moulds can easily grow at relatively low $\mathrm{pH}$ values, so the the tomato sauce having $\mathrm{pH}$ arround 4 is an excelent medium for the fungal growth. The growth of the fungus isolated from the rotten apricot is presented in Figure 2 (2.1 and 2.2). The microorganism grows very quickly and intensively on the Sabourand-dextrose solid medium in the Petri Dish (Figure 2.1).

(1)

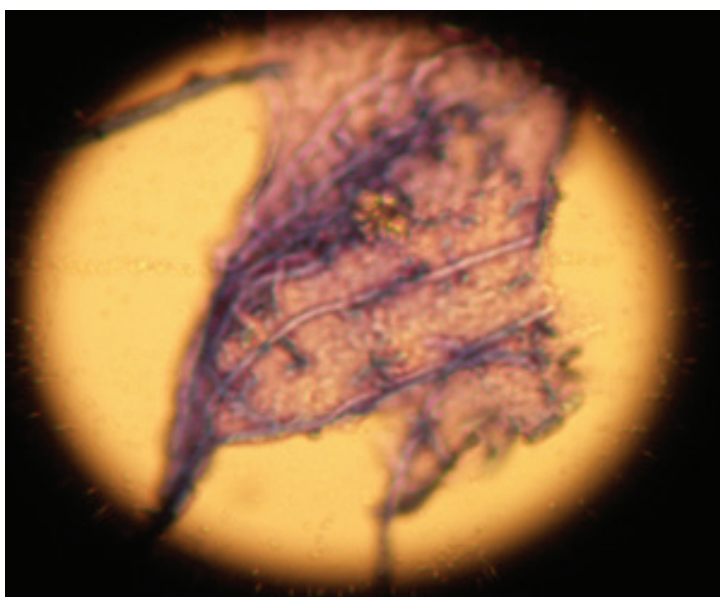

(2)
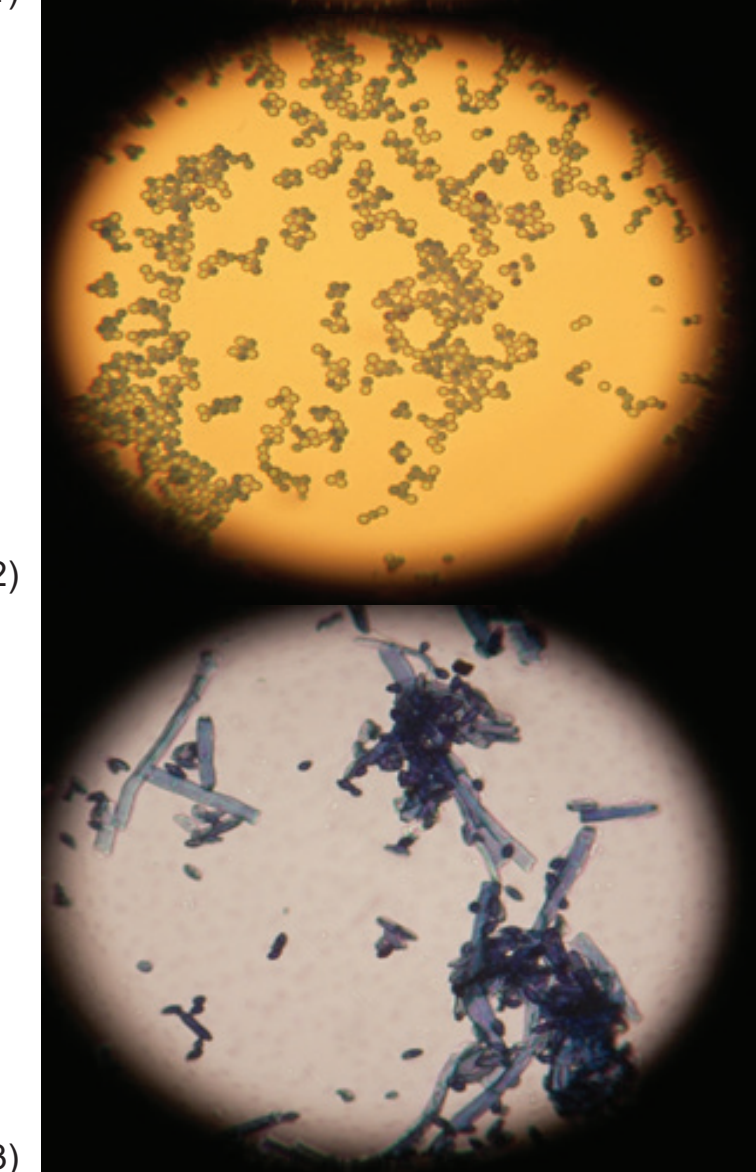

Figure 3. Microscopic appearance of the moulds isolated from: 1 (tomato-green mould), 2 (tomato-grey mould), 3 (apricotgreen mould), 400 times enlarged
The isolated fungi were purified by multiple dilution and the one isolated from the rotten appricot has been chosen as an infecting strain due to its robustness, resistance to infections of other microbial strains and a high density of growth. The isolated fungal strains were also microscopicaly examined. The results are presented in Figure 3. It is interesting to note that in Figure 3.3, the hyphal structure of the microorganism can be recognized.

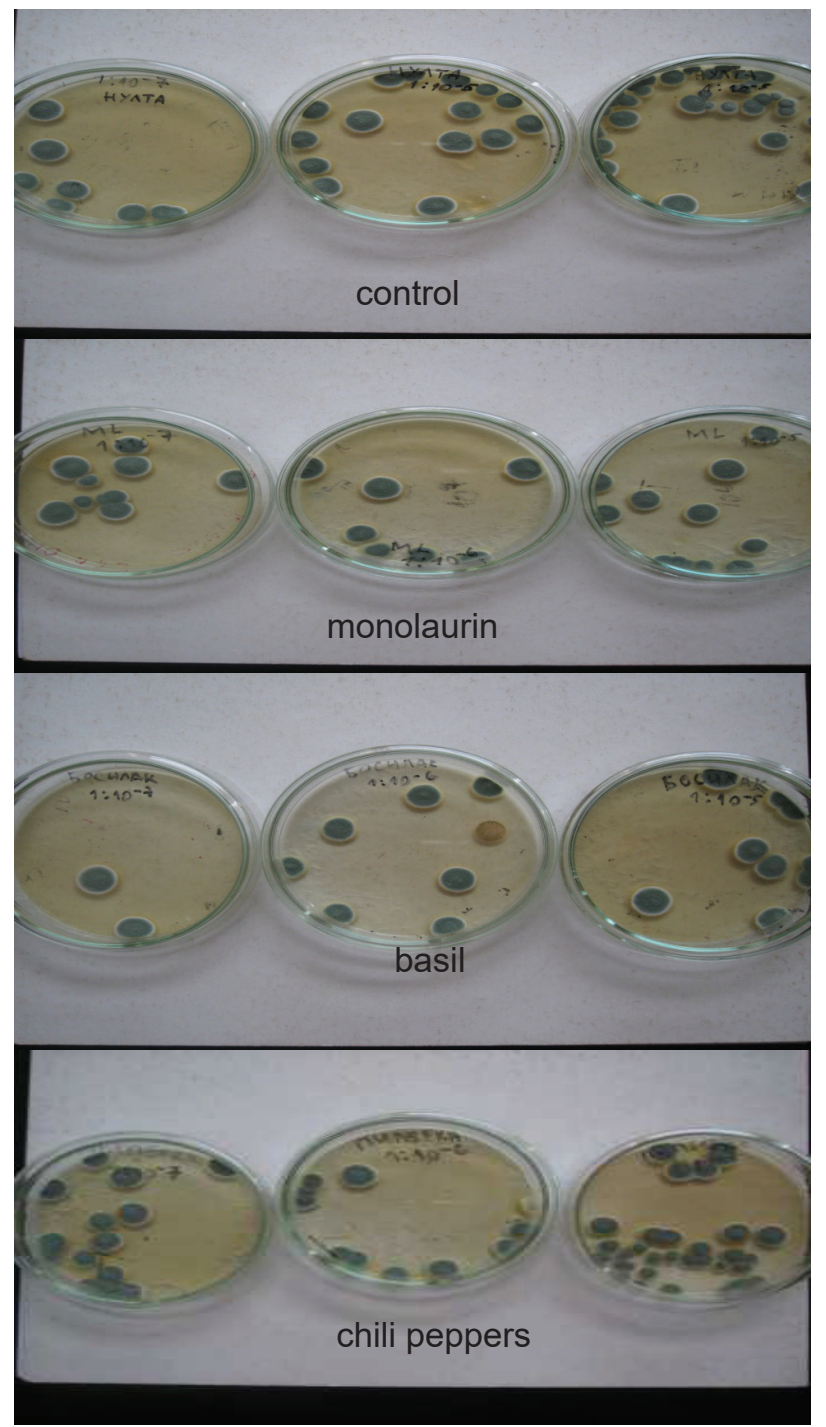

Figure 4. The growth of the fungus isolated from tomato sauce containing different additives: control, chili peppers, monolaurin and basil. The dilutions of the samples used were $10^{-7}, 10^{-6}$ and $10^{-5}$

Microbiological tests of the infected tomato products

The fungus presented as the fungus number 3 i.e. the apricot green mould was selected as an infecting microorganism for tomato sauces containing different food additives as antimicrobial agents. After the infection of different sauces $\left(3 \mathrm{~mL}\right.$ with the concentration of $1 \times 10^{9}$ cells $\left./ \mathrm{mL}\right)$ and incubation, the samples of $25 \mathrm{~mL}$ were taken and grown colonies were counted according to the procedure described in the M\&M section. The appearance of the grown fungus, from the samples prepared with dilu- 
tions of $10^{-7}, 10^{-6}, 10^{-5}$ is presented in Figure 4 and the total cell counts of the colonies formed are presented in Table 1.

From the presented results, it is obvious that monolaurin, cinnamon and basil pronounced the antifungal activity. That monolaurin affects both vegetative cells and reproductive organelles of the fungus, has already been evaluated [17]. Kabara and Marshall [15] also claimed that monolaurin, as an antimicrobial agent having natural origin, is characterised by the antimicrobial activity not only in vitro, but its strong antimicrobial effect continues after its consumption in the human organism, and in this way it strengthens the immune system of the body. Thus, these kinds of food products that contain biologically active agents are considered as nutraceuticals, i.e. functional food products.

Table 1. Preliminary determination of the antimicrobial activity of additives used in the tomato sauce production, according to the total cell count of the fungus

\begin{tabular}{lc}
\hline Tomato sauce type & $\begin{array}{l}\text { Total cell count } \\
\left(c f u / m L \times 10^{6}\right)\end{array}$ \\
\hline Monolaurin & $3 \pm 1$ \\
Basil & $8 \pm 1$ \\
Chilli peppers & $10 \pm 5$ \\
Salt & $15 \pm 5$ \\
Control & $15 \pm 5$ \\
Cinnamon & $6 \pm 1$ \\
Garlic & $15 \pm 5$ \\
\hline
\end{tabular}

Basil leaves, used as spices in the tomato sauce have also shown a strong antifungal activity (total cell count of $\left.8 \pm 1 \mathrm{cfu} / \mathrm{mL} \times 10^{6}\right)$. That the essential oil from basil leaves, one of the most frequently used spices in the food production industry are well known to have a broad range of antimicrobial activities towards various gram positive bacteria (Streptococcus, Staphylococcus), gram positive bacteria (Escherichia, Pseudomonas) and fungi (Aspergillus, Penicillium), has already been reported [9].

The antifungal activity of cinnamon, as a spice used in tomato products, has also a distinguished value $(6 \pm 1$ $\left.\mathrm{cfu} / \mathrm{mL} \times 10^{6}\right)$. According to the literature, this very special spice is very rich in essential oils with a strong antimicrobial effect towards wide varieties of microbial strains [4, 5]. There are opinions that these essential oils negatively affect the cell replication mechanism and inhibit the activity of the enzymes responsible for the replication of microbial cells, which is a probable explanation for their strong antimicrobial effect [5]. The use of salt and garlic as additives failed to show any antimicrobial effect, while chilli peppers showed a very mild antimicrobial effect towards the examined wild fungal strain.

\section{Conclusions}

Several food additives (spices) were used in the model tomato sauce production with preliminary evaluation of their antimicrobial activity. The basil leaves, cinnamon powder, garlic powder, salt and milled chilli peppers as spices, and monolaurin as a food supplement were all used as additives of the produced tomato sauces. Monolaurin, basil and cinnamon showed the strongest antifungal activity, the property that can be used in the creation of the preservation process which is safe but less harmful for biologically active compounds.

\section{References}

[1] A. Ruiz Celma, T. Delgado, H. Garcia, B. F. Cuadros, F. Lopez-Rodriguez. Characterisation of industrial tomato by-products from infrared drying process, Food and Bioproducts Processing, 87 (2009) 303-311.

[2] G. Domenech-Asensi, F. J. Garcia-Alonso, E. Martinez, M. Santaella, G. Martin-Pozuelo, S., Bravo, M. J. Periago. Effect of the addition of tomato paste on the nutritional and sensory properties of mortadella. Meat Science, 93 (2)(2012) 213-219.

[3] M. W. Siddiqui, I. Chakraborty, J. F. Ayala-Zavala, R. S Dhua. Advances in minimal processing of fruits and vegetables. Journal of Scientific \& Industrial Research 70 (2011) 823-834.

[4] H. Su-Chen, C. Ku-Shang, C. Pei-Wen. Inhibition of neuroinflamation by cinnamon and its main components, Food Chemistry, 138 (2013) 2277-2278.

[5] J. Todd, M. Friedman, J. Patel, D. Jaroni, S. Ravishankar. The antimicrobial effect of cinnamon leaf oil against multi-drug resistant Salmonella Newport on organic leafy greens. Intern. Journal of Food Microbiology, 166 (1) (2013) 193-199.

[6] H. Haciseferogullari, M. Ozcan, F. Demir, S. Calisir. Some nutritional and technological properties of garlic (Allium sativum L.). Journal of Food Engineering, 68 (4) (2005) 463-469.

[7] H. R. Cheisari, V. R. Ranjbar, Antioxidative and antimicrobial effects of garlic in ground camel meat. Turkish Journal of Veterinary \& Animal Science, 36 (2012) 13-20.

[8] P. D. Serrone, M. Nikoletti. Antimicrobial activity of a neem cake extract in a broth model meat system. International Journal of Environmental Research and Public Health, 10 (2013) 3282-3295.

[9] K. J. Joshi. Chemical composition and antimicrobial activity of the essential oil of Ocimum basilicul L (sweet basil) from Western Ghats of North West Karnataka, India Ancent Science of Life, 33 (3) (2014) 151-156.[10] F. da Silva, R. H. S. Santos, N. J. de Andarde, L. C. A. Barbosa, V. W. D. Casali, R. R. de Lima, R. de M. Passarinho. Basil conservationaffected by cropping season, harvest time and storage period. Presqisa Agropecuaria Brasileira, 40 (4) (2005) 323-328.

[10] D. I. Batovska, I. T. Todorova, I. V. Tsvetkova,. H. M Najdenski,. Antimicrobial study of the medium chain fatty acids and their 1-monoglycerides: individual effects and synergistic relationships. Polishv Journal of Microbiol58 (2009) 43-47.

[11] M. A. Zare, S. M. R. Rohani, M. Raeisi, S. H. J. Hosseini,M. 
Hashemi, Antibacterial effects of monolaurin, sorbic acid and potassium sorbate on Staphylococcus aureus and Escherichia coli. Journal of Food Quality and Hazards Control, 1 (2014) 52-55.

[12] Z. Rihakova, V. Filip, M. Plockova, J. Šmidrkal, R. Červenkova, Inhibition of Aspergillus niger DMF 0801 by monoacyl-glycerols prepared from coconut oil. Czech Journal of Food Science, 20 (2002) 48-52.

[13] I. Mladenoska, The potential application of novel beeswax edible coatings containing coconut oil in the minimal processing of fruits. Advanced Technologies, 1(2) (2012) 26-34.
[14] J. J. Kabara, D. L. Marshall. Medium-Chain Fatty Acids and Esters, in: P.M. Davidson, J.N. Sofos, A. L. Branen, (Eds.) Antimicrobials in Food, CRC Press, Taylor \& Francis Group, Boca Raton, USA, 2005, pp. 327-361.

[15] A. D. Ibrahim, K. Musa, A. Sani, A. A. Aliero, B. S. Yusuf. Microorganisms associated with the production of volatile compounds in spoiled tomatoes. Research in Biotechnology, 2 (2) (2011) 82-89.

[16] I. Mladenoska, V. Nikolovska, L. Puzderliska Model meat pasteurized sausages enreached with monolaurin as nutraceuticals with pronounced antimicrobial properties, Food and Feed Research, 39 (2) (2012) 69-78.

Izvod

\section{PRELIMINARNO ISPITIVANJE ANTIMIKROBNE AKTIVNOSTI POJEDINIH ZAČINA KOJI SE KORISTE KAO ADITIVI U PROIZVODNJI SOSOVA OD PARADAJZA}

Irina Mladenoska, Darko Dimitrovski

Departman za Prehrambenu tehnologiju i biotehnologiju, Tehnološko-metalurški fakultet, Univerzitet "Sveti Ćiril i Metodije", Skopje, Makedonija

Cilj ovog rada je preliminarno ispitivanje antimikrobne aktivnosti različitih aditiva koji se mogu koristitu u proizvodnji različitih sosova od paradajza. Za ovu namenu, u procesu proizvodnje paradajz sosa korišćeno je nekoliko različitih začina i monolaurin kao dijetetski dodatak ishrani. Začini koji su upotrebljeni su: beli luk u prahu, listovi bosiljka, cimet u prahu, mlevena, ljuta, crvena paprika i kuhinjska so. Nekoliko različitih vrsta divljih gljiva bile su izolovane od trulih paradajza i trulih kajsija. Ova druga gljiva, izolovana od trule kajsije, bila je korišćena kao infektivni mikroorganizam za pripremljene paradajz sosove. Testovi primeraka inficiranih paradajz sosova koji kao additive sadrže monolaurin, bosiljak i cimet imali su ukupan broj ćelija od $3 \pm 1,8 \pm 1$ i $6 \pm 1 \mathrm{cfu} / \mathrm{mL} \times 10^{6}$. Ovi rezultati su pokazali da se tri odabrana aditiva karakterišu sa najvećim potencijalom za upotrebu kao antimikrobni aditivi u procesu proizvodnje paradajz sosova.
(ORIGINALNI NAUČNI RAD) UDK 664.843.5:635.64:635.7:579

Ključne reči: paradajz sos, monolaurin, bosiljak, cimet, luk, ljute paprika, antimikrobna aktivnost 